\title{
The Effect of Seeds and Fruit Pulp of Adansonia digitata L. (Baobab) on Ehrlich Ascites Carcinoma
}

\author{
Fahmy G. Elsaid ${ }^{1,2}$ \\ ${ }^{1}$ Zoology Department, Faculty of Science, Mansoura University, Mansoura, Egypt; ${ }^{2}$ Biology Department, Science College, King \\ Khalid University, Abha, KSA. \\ Email: fahmygad@mans.edu.eg
}

Received March 20 $0^{\text {th }}, 2013$; revised April 20 ${ }^{\text {th }}, 2013$; accepted April 27 $7^{\text {th }}, 2013$

Copyright (C) 2013 Fahmy G. Elsaid. This is an open access article distributed under the Creative Commons Attribution License, which permits unrestricted use, distribution, and reproduction in any medium, provided the original work is properly cited.

\begin{abstract}
The anti-tumor effect of Adansonia digitata on Ehrlich ascites carcinoma cells (EAC) is still novel talk. This study is focusing on the role of the extracts of seeds and the fruit pulp of Adansonia on the antioxidants activity and the molecular changes of pro-apoptic and anti-apoptic genes expression before and after the treatment of EAC cells bearing mice. Adult female BALB/C mice were used in this study; subgrouped randomly into four groups: control group (non-tumorized); EAC tumorized group, mice was i.p. inoculated with $2.5 \times 10^{6}$ of EAC cells; EAC + extract of seeds group, tumorized mice was inoculated with $2.5 \times 10^{6}$ of EAC cells and i.p. administered with the extract of Adansonia seeds $\left(300 \mathrm{mg} / \mathrm{kg} \mathrm{b}\right.$. wt.); EAC+ fruit pulp group, tumorized mice was inoculated with $2.5 \times 10^{6}$ of EAC cells and i.p. administered with the extract of Adansonia fruit pulp $(300 \mathrm{mg} / \mathrm{kg} \mathrm{b}$. wt.). The antioxidant enzymes were inhibited in EAC cells and in ascetic fluid of tumorized mice. Also the oxidative stress was increased significantly in EAC cells bearing mice. The liver was affected with the transplantation of EAC cells as reflected by the imbalance in the antioxidants and oxidants in the EAC cells bearing mice. Moreover, the molecular changes in $p 53$ and B-cell lymphoma $(B c l-2)$ genes expression were recorded in EAC cells bearing mice. The extracts of adansonia have a promising role as antioxidant action due to their antioxidant effect as they ameliorate the imbalance in antioxidants and oxidants balance. The plant extract has anti-apoptosis role by restoring the P53 and Bcl-2 genes expression. Also the plant has antitumor action as they restore tumor markers levels such as $\alpha$-l-fucosidase and arginase to the normal levels.
\end{abstract}

Keywords: Ehrlich Ascites Carcinoma; Tumor Markers; Antioxidants; Oxidative Stress; Gene Expression; Adansonia digitata; Baobab

\section{Introduction}

Ehrlich ascites carcinoma (EAC) is transplantable tumors and they were taken into concern in the last 2 to $3 \mathrm{dec}-$ ades. Experimental tumors have vital significance for the purposes of modeling, and EAC is one of the top and famed cases. EAC is indicated to as an undifferentiated carcinoma, and has high transplantable capability, noregression, rapid proliferation, shorter lifespan and $100 \%$ malignancy [1]. EAC is used as ascites or a solid form due to these purposes, that is, if ascites fluid contains the tumor cell that injects intraperitoneal, the ascites form is obtained, but if it contains subcutaneously, a solid form is obtained [2]. In 4 or 6 days after inoculation, the ascites fluid is formed and a total of 5 or $12 \mathrm{~mL}$ ascites fluid is accumulated [3]. Following the inoculation into the peritoneal cavity of mice, EAC cells proliferating by which the number of cells increases exponentially, and a plateau phase followed by are sting period, in which a number of cells stay almost constant [4]. Bulan [5] reported that the number of EAC cells increased exponentially in the 9th day after intraperitoneal transplantation of $3 \times 10^{6}$ EAC cells. After inoculation of EAC, the host animal died due to the pressure exerted by the tumor volume and/or the damage that resulted from the tumor [6]. For the accumulation of ascites fluid, whether or not the tumor cells secrete a vascular permeability factor that stimulated the accumulation of ascites fluid was investigated that damage changed the vascular permeability [7]. Altun [8] in another study investigated the liver regeneration in mice with EAC and reported that tumor growth stimulated the regenerative growth.

Oxidative stress exerts toxic effects on cells and is potent in inducing apoptosis [9]. The inhibition of superoxide dismutase (SOD) and catalase (CAT) activities as a 
result of EAC growth was reported in liver [10]. Aktas [6] and Lobo [11] showed that the antioxidant level such as glutathione (GSH) concentration decreased in EAC cells. Similar decrease in the activity of SOD, CAT, GSH contentand increase in lipid peroxidation was observed in the EAC and the liver of EAC-bearing mice [12]. Overproduction of reactive oxidative stress in SOD antisensetransfected cells was reported to increase pro-apoptotic proteins Bad and Bax and to decrease anti-apoptotic proteins $B c l-2$ and $B c l-x L$ by regulating their phosphorylation and ubiquitination [13]. However, $\mathrm{Xu}$ [14] found that the expression of some antioxidant enzymes such as SOD presented a more complex pattern, which differed from the expression of $\mathrm{Bcl}-2$. Among the positive and negative regulators of apoptosis, $p 53$, the tumor suppressor gene, has an important role against cancer as it suppresses tumor growth through two mechanisms, cell cycle arrest and apoptosis [15]. Cell growth and its proliferation are two tightly linked processes. Both are characterized by increasing protein synthesis which are achieved by changes in the activity of ribosomal biogenesis and p53 expression [16]. Bax, thepro-apoptotic member of $\mathrm{Bcl}-2$ family, is a $p 53$ target and istransactivated in a number of systems during p53-mediate-dapoptosis [17]. The up-regulation of Bax expression and down-regulation of $\mathrm{Bcl}-2$ have been well demonstrated during apoptosis [18]. Also Cho [19] showed that $\mathrm{H}_{2} \mathrm{O}_{2}$-induced apoptosis was accompanied by changes in apoptosisrelated factors such as the $\mathrm{Bcl}-2$ family of regulatory proteins. The intracellular concentration of the anti-apoptotic protein $\mathrm{Bcl}-2$ acts as a molecular indicator that influences whether a cell lives or dies [20]. All these studies demonstrated that pro- and anti-apoptotic proteins are the important factors deciding the fate of neoplastic cells.

Some researchers reported that some plant extracts were effective against EAC [21]. Although there are a lot of floristic studies, approximately $10 \%$ of the 250,000 complex plant species only were investigated at their chemical and pharmacological sites [7]. The exploring of new toxic agents from natural products has been concerned in collaboration with scientists worldwide [22]. Kamatou [23] reported that it was an excellent antioxidant due to the vitamin $\mathrm{C}$ content which was seven to ten times higher than the vitamin $\mathrm{C}$ content of oranges. Kamatou [23] suggested that consumption of $A$. digitata fruit might play an important role in resistance to liver damage in areas where baobab was consumed [24]. Phytochemical investigation showed the presence of flavonoids, phytosterols, amino acids, fatty acids, vitamins and minerals. The seeds are a source of significant quantities of lysine, thiamine, calcium and iron [23]. Recently, the European Commission authorised the import of baobab fruit pulp as a novel food [25] and it was approved in
2009 by the Food and Drug Administration as a food ingredient in the United States of America [26]. Due to the high demand for commercial baobab products in EU and United States, this tree with its edible fruits needs to be conserved and treasured [27].

Upon of these, the study aimed to investigate the role of Adansonia digitata on the biochemical changes associated with the EAC transplantation in mice. Moreover, this is may be the first topic that deals with the vital role of methanolic extracts of seeds and dry powder fruitpulp of Adansonia digitata in regulating the role of pro- and anti-apoptotic genes in tumor cells.

\section{Material and Methods}

\subsection{About Plant}

Baobab (Adansonia digitata L.; Bombacaceae) is a large tree with an unusual shape growing in the drier parts of Africa (Sudan). The plant has a wide range of uses, not only as a food and beverage, but also medicinally to treat fevers and dysentery [28]. In recent years, there has been an upsurge of interest in the development of baobab fruits as a botanical dietary supplement in the United States. The fruit pulp affords high levels of vitamin $\mathrm{C}$ (range $2.8-3 \mathrm{~g} / \mathrm{kg}$ ) and has also been documented as having high antioxidant potency [29]. An aqueous extract of $A$. digitata fruit pulp has shown anti-inflammatory and analgesic effects in rat models, but at quite a high dose range (400 - $800 \mathrm{mg} / \mathrm{kg}$, p.o.) [30]. The various plant parts of baobab have been subjected to relatively few studies phytochemically, and, for example, a number of proanthocyanidins of previously known structure were reported as major constituents from an $80 \%$ methanol extract of the fruit pulp [31]. The acute toxicity of baobab fruit pulp extract was tested in vivo on rats and the results showed that the LD50 was $8000 \mathrm{mg} / \mathrm{kg}$ following parenteral administration suggesting low toxicity [30].

\subsection{Plant Extract}

The air-dried and powdered of seeds and fruit pulp (10 g) were extracted with $200 \mathrm{ml}$ methanol by Soxhlet extraction for $18 \mathrm{hrs}$. The residue was dried overnight and then extracted with $250 \mathrm{ml}$ water by using a shaking water bath at $70^{\circ} \mathrm{C}$ for 2 hrs. The obtained methanolic and water extracts were filtered and evaporated by using a rotator evaporator. The dried extracts of seeds and fruits pulp were stored at $-80^{\circ} \mathrm{C}$ until use. The method of extraction is used herein with a little modification as Mothana [32].

\subsection{Tumor Cell Line}

A line of Ehrlich Ascites Carcinoma (EAC) obtained from Egyptian National Cancer Institute, Cairo, Egypt. 
The tumor line was maintained in female BALB/C mice by weekly intraperitoneal injection of $2.5 \times 10^{6}$ cells/ mouse $/ 0.25 \mathrm{ml}$ of phosphate buffer saline (PBS). EAC cells counts were done in a Neubauer hemocytometer using the trypan blue dye. Cell viability was always found to be $95 \%$ or more. Tumor cell suspensions were prepared in PBS. EAC cell line is characterized by its reasonable rapid growth which could not kill the animal due to the accumulation of Ascites.

\subsection{Animal Grouping}

The experiment has been used three month old female $\mathrm{BALB} / \mathrm{c}$ mice $40 \pm 5 \mathrm{~g}$. The local committee approved the design of the experiments and the protocol conforms to the guidelines of the National Institutes of Health (NIH). All measures were taken to minimize the number of mice used and their suffering. Animals were kept in vivarium, housed in polycarbonate cages, 10 mice per cage, at a constant room temperature of $23^{\circ} \mathrm{C} \pm 1^{\circ} \mathrm{C}$ with a 12-h light/dark cycle (light on from 7:00 AM till 7:00 PM). Standard rat chow diet and water were available $a d$ libitum. Animals were divided into four groups (Ten/ group); Control group: mice were received no treatment; Ehrlich Ascites Carcinoma (EAC) group: mice were inoculated intraperitoneally with of $2.5 \times 10^{6}$ cells/mouse/ $0.25 \mathrm{ml}$ of PBS; EAC+ seed extract group: Tumorized mice were daily intraperitoneally administered with seed extract of Adansonia at $300 \mathrm{mg} / \mathrm{kg}$ b. wt. for 14 days; EAC + fruits extract group: Tumorized mice were daily intraperitoneally administered with fruits extract of $A d$ ansonia at $300 \mathrm{mg} / \mathrm{kg} \mathrm{b}$. wt. for 14 days. At the end of the experimental period mice were sacrificed by decapitation then blood, ascites fluid, EAC cells, and liver tissue were collected from each group. EAC cells from EAC bearing-mouse were homogenized then centrifuged at $2000 \mathrm{rpm}$ for $10 \mathrm{~min}$ at $4^{\circ} \mathrm{C}$. The ascetic fluid obtained was used for the estimation of the antioxidant enzymes such as SOD, GSH-Px in different animal groups. Also the EAC cells pellet and liver tissues were immediately homogenized in a phosphate buffer solution $\mathrm{pH} 7.4$ and centrifuged at $2000 \mathrm{rpm}$ for $10 \mathrm{~min}$ at $4^{\circ} \mathrm{C}$. The liver samples were then rinsed in ice-cold normal saline followed by cold $0.15 \mathrm{M}$ Tris- $\mathrm{HCl}$ ( $\mathrm{pH}$ 7.4), blotted dry, and weighed. A $10 \% \mathrm{w} / \mathrm{v}$ homogenate was prepared in $0.15 \mathrm{M}$ Tris- $\mathrm{HCl}$ buffer; of which a portion was utilized for the estimation of lipid peroxidation and $\mathrm{H}_{2} \mathrm{O}_{2}$ and a second portion was used for the estimation of GSH after precipitating proteins with TCA. The supernatant of liver tissues, EAC cells, ascites fluid and sera were stored at $-80^{\circ} \mathrm{C}$ until be used in the biochemical assay. The EACcells that be used in the molecular study was stored at $-80^{\circ} \mathrm{C}$ until be further analyzed.

\subsection{Enzymatic Assay}

\subsubsection{Superoxide Dismutase (SOD) Activity}

This assay relied on the ability of the enzyme to inhibit the phenazinemethosulphate-mediated reduction of nitrobluetetrazolium dye [33].

\subsubsection{Glutathione Peroxidase (GSH-Px) Activity}

The activity was measured by the method described by Ellman [34]. Briefly, the reaction mixture contained 0.2 $\mathrm{ml}$ of $0.4 \mathrm{M}$ phosphate buffer ( $\mathrm{pH} 7.0$ ), $0.1 \mathrm{ml}$ of $10 \mathrm{mM}$ sodium azide, $0.2 \mathrm{ml}$ of supernatant (homogenate on 0.4 $\mathrm{M}$ phosphate buffer, $\mathrm{pH} 7.0$ ), and $0.2 \mathrm{ml}$ glutathione, 0.1 of $0.2 \mathrm{mM} \mathrm{H}_{2} \mathrm{O}_{2}$. The reaction content was incubated at $37^{\circ} \mathrm{C}$ for $10 \mathrm{~min}$. The reaction was arrested by adding 0.4 $\mathrm{ml}$ of $10 \% \mathrm{TCA}$ and then centrifuged. The molar extinction coefficient for NADPH is $6220 \mathrm{mM}^{-1} \cdot \mathrm{cm}^{-1}$ at 340 $\mathrm{nm}$.

\subsubsection{GSH (GSH) Content}

GSH served as an antioxidant, reacting with free radicals and organic peroxides, in amino acid transport, and as a substrate for the GSH-Px and glutathione-S-transferase in the detoxification of organic peroxide and metabolism of xenobiotics, respectively. A tissue was homogenized in $10 \mathrm{ml}$ cold buffer $(50 \mathrm{mM}$ potassium phosphate, $\mathrm{pH}$ $7.5,1 \mathrm{mM}$ EDTA) per gram tissue. Centrifuge at 100,000 $\mathrm{x} \mathrm{g}$ for $15 \mathrm{~min}$ at $4^{\circ} \mathrm{C}$ was performed. The supernatant was transferred into a new sterile tube for assay and the rest of the samples stored at $-80^{\circ} \mathrm{C}$ for further work. The method based on the reduction of 5,5'-Dithiobis(2-nitrobenzoic acid) (DTNB) with GSH to produce a yellow compound. The reduced chromogen directly proportional to GSH concentration and its absorbance can be measured at $405 \mathrm{~nm}$ [35].

\subsubsection{Malondialdehyde (MDA) Level}

The thiobarbituric acid reactive substances (TBARS) as malondialdehyde were estimated by the method of Ohkawa [36]. Briefly, to $0.2 \mathrm{ml}$ of homogenate, $0.2 \mathrm{ml}$ of $40 \%$ sodium dodecylesulphate, $1.5 \mathrm{ml}$ of $20 \%$ acetic acid (prepared in $0.27 \mathrm{M}$ of $\mathrm{HCl}$ ) and $1.5 \mathrm{ml}$ of $0.5 \%$ thiobarbituric acid were mixed together. The mixture was heated for $60 \mathrm{~min}$ at $95^{\circ} \mathrm{C}$ in a water bath to give a pink color. The mixture was then centrifuged at $3500 \mathrm{rpm}$ for $10 \mathrm{~min}$. Finally absorbance of the supernatant layer was read spectrophoto-metrically at $532 \mathrm{~nm}$, the molar extinction coefficient factor equal $1.56 \times 10^{5} \mathrm{M}^{-1} \cdot \mathrm{cm}^{-1}$.

\subsubsection{Hydrogen Peroxide $\left(\mathrm{H}_{2} \mathrm{O}_{2}\right)$ Level}

Its concentration was measured according to the method of Aebi [37]. The principle of this method based on that, in the presence of peroxidase, $\mathrm{H}_{2} \mathrm{O}_{2}$ reacts with 3,5-dichloro-2-hydroxy benzene sulfonic acid (DHBS) and 4-aminophenazone (AAP) to form a chromophore. The 
absorbance was read spectrophotometrically at $510 \mathrm{~nm}$.

\subsubsection{Bilirubin Content}

The reaction between bilirubin and the diazonium salt of sulphanilic acid produced azobilirubin which shows a maximum absorption at $535 \mathrm{~nm}$ in an acid medium [38].

\subsubsection{Statistical Analysis of Biochemical Data}

The biochemical data recorded were expressed as mean \pm $\mathrm{SD}$ and statistical and correlation analyses were undertaken using the One-way ANOVA followed by a posthoc LSD (Least Significant Difference) test. A $P$ value $<$ 0.05 was statistically significant. A Statistical analysis was performed with the Statistical Package for the Social Sciences for Windows (SPSS, version 10.0, Chicago, IL, USA).

\subsubsection{Extraction of Total RNA from EAC Homogenates}

Total RNA was isolated from EAC pellets using RNeasy Mini Kit according to manufacturer's instructions (QIAGEN, Germany). About $100 \mu \mathrm{l}$ of homogenate was subjected to RNA extraction and the resultant RNA was dissolved in DEPC-treated water, quantified spectrophotometrically and analyzed on 1.2\% agarose gel. RNAs inhibitors were added to the samples during the RNA extraction process.

\subsubsection{Real Time PCR and Gene Expression}

1) For Pro-Apoptic and Anti-Apoptic Genes (P53 and Bcl2)

The extracted RNA was subjected to Real Time PCR reaction to examine the expression $p 53$ and $B c l 2$ genes in $\mathrm{EAC}, \mathrm{EAC}+$ Seeds extract and EAC + fruits extract of Adansonia using specific primers in the presence of glyceraldehyde-3-phosphate dehydrogenase (GPDH) as a housekeeping gene. The Real time reaction consists of $12.5 \mu$ of $2 \mathrm{X}$ Quantitech SYBR ${ }^{\circledR}$ Green RT Mix (Fermentaz, USA), $2 \mu \mathrm{l}$ of the extracted RNA (50 ng/ $\mu \mathrm{l}), 1 \mu \mathrm{l}$ of $25 \mathrm{pM} / \mu \mathrm{l}$ forward (F) primer, $1 \mu \mathrm{l}$ of $25 \mathrm{pM} / \mu \mathrm{l}$ reverse (R) primer (Table 1), $9.5 \mu \mathrm{l}$ of RNAase free water for a total of $25 \mu \mathrm{l}$. Samples were spun before loading in the rotor's wells. The real time PCR program was performed as follows: initial denaturation at $95^{\circ} \mathrm{C}$ for $10 \mathrm{~min}$; 40 cycles of $64^{\circ} \mathrm{C}$ for $15 \mathrm{sec}$ for $p 53$, annealing at $63^{\circ} \mathrm{C}$ for $30 \mathrm{sec}$ for $\mathrm{Bcl} 2$ and extension at $72^{\circ} \mathrm{C}$ for $30 \mathrm{sec}$. Data acquisition performed during the extension step. This reaction was performed using Rotor-Gene 6000 system (QIAGEN, USA).

\subsubsection{Molecular Data Analysis}

Comparative quantitation analysis was performed using Rotor-Gene-6000 Series Software based on the following equation:

$$
\text { Ratio target gene expression } \frac{\text { Fold change in target gene expresion }\left(\frac{\text { sample }}{\text { control }}\right)}{\text { Fold change in reference gene expresion }\left(\frac{\text { house keeping gene }}{\text { control }}\right)}
$$

Real-time PCR data of all samples were analyzed with appropriate bioinformatics and statistical program for the estimation of the relative expression of genes using real-time PCR and the result normalized to its gene (Reference gene). The data were statistically evaluated, interpreted and analyzed using Rotor-Gene-6000 version 1.7.

\section{Results}

As in Table 2, the sera bilirubin and tumour markers such as arginase and alpha-l-fucosidase levels were significant increase in the transplant EAC group $(p \leq 0.001)$ when compared with the control group. The extracts of seeds and pulp fruits of Adansonia showed significant decrease in the tumor markers when compared with EAC group. Moreover, the level of bilirubin was ameliorated with the administration of the extracts of seeds and fruits of Adansonia.

The EAC group in Table 3, showed very high significant decrease $(P \leq 0.001)$ in the sera superoxide dismutase and glutathione peroxidase activities and reduced glutathione content when compared with control group. The oxidative stress was determined as an increment in

Table 1. Primers nucleotides sequence used in this study.

\begin{tabular}{ccc}
\hline Primers name & Primer sequence from 5'-3' & Annealing temp. \\
\hline P53 & F-AGGGATACTATTCAGCCCGAGGTG & $64^{\circ} \mathrm{C}$ \\
$B c l 2$ & R-ACTGCCACTCCTTGCCCCATTC & $63^{\circ} \mathrm{C}$ \\
FPDH (Housekeeping gene) & F-ATGTGTGTGGAGAGCGTCAACC & $60^{\circ} \mathrm{C}-65^{\circ} \mathrm{C}$ \\
\hline
\end{tabular}

GPDH: Glyceraldehyde-3-phosphate dehydrogenase. 
Table 2. Serum bilirubin and tumor markers of different treated groups.

\begin{tabular}{|c|c|c|c|c|}
\hline Groups Parameters & Control & EAC & EAC+ Seeds Extract & EAC+ Fruit Extract \\
\hline Bilirubin (U/dl) & $0.51 \pm 0.08$ & $1.1 \pm 0.12^{* * * 1 \text { III }}$ & $0.87 \pm 0.14^{* * * 1 \tilde{I}}$ & $0.79 \pm 0.02^{* * * 1 . ั \mathrm{II}}$ \\
\hline Arginase (U/dl) & $31.8 \pm 2.2$ & $110.6 \pm 5.1^{* * *}$ & $63.6 \pm 2.5^{* * * 1 \text { III }}$ & $72.0 \pm 1.6^{* * * \text { III }}$ \\
\hline L-Fucosidase (U/dl) & $21.8 \pm 10.4$ & $75.1 \pm 6.9^{* * *}$ & $56.9 \pm 11.2^{* * * 1.1}$ & $53.0 \pm 3.9^{* * * 1 \text { III }}$ \\
\hline
\end{tabular}

All data \pm standard deviation (SD), each group equal 5 rats, $p \leq 0.001^{* * *}$, represented the comparison of EAC, EAC + Seeds Extract and EAC + Fruit Extract with the control group; $p \leq 0.001^{\text {III }}$, represented the comparison of EAC+ Seeds Extract and EAC+ Fruit Extract with the EAC group.

Table 3. The serumantioxidants activities and oxidative stress in different treated groups.

\begin{tabular}{|c|c|c|c|c|}
\hline Groups Parameters & Control & EAC & EAC+Seeds Extract & EAC+Fruit Extract \\
\hline $\mathrm{SOD}(\mathrm{U} / \mathrm{ml})$ & $3.5 \pm 0.1$ & $1.3 \pm 0.2^{* * *}$ & $2.6 \pm 0.4^{* * * 1 \text { III }}$ & $2.3 \pm 0.4^{* * *} \mathrm{I} \tilde{\mathrm{II}}$ \\
\hline GSH-Px (U/ml) & $162.6 \pm 19.7$ & $55.2 \pm 7.8^{* * *}$ & $74.1 \pm 5.7^{* * * 1}$ & $77.6 \pm 5.9^{* * * 1 \check{I}}$ \\
\hline GSH (mg/mg protein) & $28.7 \pm 3.3$ & $14.1 \pm 0.87^{* * *}$ & $18.4 \pm 1.78^{* * * 1 \check{I}}$ & $18.1 \pm 1.5^{* * * 1} \check{I} \mathrm{I}$ \\
\hline $\operatorname{MDA}(\mathrm{n} \mathrm{mol} / \mathrm{ml})$ & $82.7 \pm 5.3$ & $124.2 \pm 9.1^{* * *}$ & $101.8 \pm 9.1^{* * *}$ I II & $98.2 \pm 5.9^{* * * 1} \tilde{I I I}$ \\
\hline $\mathrm{H}_{2} \mathrm{O}_{2}(\mathrm{U} / \mathrm{ml})$ & $71.1 \pm 10.7$ & $146.8 \pm 7.4^{* * *}$ & $128.1 \pm 3.8^{* * * 11 \mathrm{III}}$ & $118.9 \pm 3.6^{* * * 1} \tilde{I}$ \\
\hline
\end{tabular}

All data \pm standard deviation (SD), each group equal 5 rats, $p \leq 0.001^{* * *}$, represented the comparison of EAC, EAC + Seeds Extract and EAC + Fruit Extract with the control group; $p \leq 0.01^{\text {II }}, p<0.001^{1}$, , represented the comparison of EAC+ Seeds Extract and EAC+ Fruit Extract with the EAC group.

TBARS and $\mathrm{H}_{2} \mathrm{O}_{2}$ in the EAC group. The methanolic extracts of seeds and fruits of Adansonia ameliorate the deflection of antioxidants status as they increase the antioxidant enzymes as well as decrease the TBARS and $\mathrm{H}_{2} \mathrm{O}_{2}$ in the EAC + Seeds Extract and EAC + Fruit Extract groups when compared with EAC group.

As in Table 4 the EAC + Seeds Extract and EAC+ Fruit Extract groups showed high significant increase in the Ascites fluid superoxide dismutase and glutathione peroxidase activities and reduced glutathione content when compared with EAC group. The extracts of seeds and fruits of Adansonia showed high significant decrease the TBARS and $\mathrm{H}_{2} \mathrm{O}_{2}$ in the EAC+ Seeds Extract and EAC + Fruit Extract groups when compared with EAC group.

As in Table 5 the EAC+ Seeds Extract and EAC+ Fruit Extract groups showed high significant increase in the EAC cells superoxide dismutase and glutathione peroxidase activities and reduced glutathione content when compared with EAC group. The extracts of seeds and fruits of Adansonia ameliorate the imbalance in antioxidants status as they increase the antioxidant enzymes as well as decrease the TBARS and $\mathrm{H}_{2} \mathrm{O}_{2}$ in the EAC+ Seeds Extract and EAC + Fruit Extract groups when compared with EAC group.

The EAC group in Table 6, showed very high significant decrease $(P \leq 0.001)$ in the liver superoxide dismutase and glutathione peroxidase activities and reduced glutathione content when compared with control group. The oxidative stress was estimated as an increment in TBARS and $\mathrm{H}_{2} \mathrm{O}_{2}$ in the EAC group. The extracts of seeds and fruits of Adansonia ameliorate the imbalance
Table 4. The Ascites fluid antioxidants activities and oxidative stress in different treated groups.

\begin{tabular}{cccc}
\hline $\begin{array}{c}\text { Groups } \\
\text { Parameters }\end{array}$ & EAC & $\begin{array}{c}\text { EAC+ Seeds } \\
\text { Extract }\end{array}$ & $\begin{array}{c}\text { EAC+ Fruit } \\
\text { Extract }\end{array}$ \\
\hline $\mathrm{SOD}(\mathrm{U} / \mathrm{ml})$ & $90.4 \pm 9.7$ & $180.3 \pm 14.5^{* * *}$ & $193.6 \pm 12.1^{* * *}$ \\
$\mathrm{GSH}-\mathrm{Px}(\mathrm{U} / \mathrm{ml})$ & $101.48 \pm 6$ & $117 \pm 5.5^{* *}$ & $124.6 \pm 10.4^{* * *}$ \\
$\mathrm{GSH}(\mathrm{mg} / \mathrm{ml})$ & $19 \pm 0.98$ & $29.1 \pm 1.3^{* * *}$ & $31.1 \pm 3.3^{* * *}$ \\
$\mathrm{MDA}(\mathrm{nmol} / \mathrm{ml})$ & $145.6 \pm 8.3$ & $111.8 \pm 13.8^{* * *}$ & $126.4 \pm 11.1^{*}$ \\
$\mathrm{H}_{2} \mathrm{O}_{2}(\mathrm{U} / \mathrm{ml})$ & $17.8 \pm 1.2$ & $11.8 \pm 0.91^{* * *}$ & $12.1 \pm 0.61^{* * *}$ \\
\hline
\end{tabular}

All data \pm standard deviation (SD), each group equal 5 rats, $\mathrm{p}<0.05^{*}, p \leq$ $0.01^{* *}, p \leq 0.001^{* * *}$, represented the comparison of EAC+ Seeds Extract and EAC+ Fruit Extract with the EAC group.

Table 5. The EAC cells antioxidants activities and oxidative stress in different treated groups.

\begin{tabular}{cccc}
\hline $\begin{array}{c}\text { Groups } \\
\text { Parameters }\end{array}$ & EAC & $\begin{array}{c}\text { EAC+ Seeds } \\
\text { Extract }\end{array}$ & $\begin{array}{c}\text { EAC+ Fruit } \\
\text { Extract }\end{array}$ \\
\hline SOD (U/g protein) & $1.6 \pm 0.13$ & $2.1 \pm 0.12^{* *}$ & $1.9 \pm 0.46^{*}$ \\
$\begin{array}{c}\text { GSH-Px } \\
\text { (U/g protein) }\end{array}$ & $92 \pm 4.9$ & $104.5 \pm 8.4^{* *}$ & $110.9 \pm 7.4^{* * *}$ \\
$\begin{array}{c}\mathrm{GSH} \text { (U/g protein) } \\
\text { MDA (n mol/g } \\
\text { protein) }\end{array}$ & $32.9 \pm 17.3$ & $46.6 \pm 27.7^{* * *}$ & $43.9 \pm 29.4^{* * *}$ \\
$\begin{array}{c}\mathrm{H}_{2} \mathrm{O}_{2} \text { (U/g protein) } \\
\text { (U) }\end{array}$ & $15.7 \pm 11.9$ & $121.8 \pm 6.8^{* * *}$ & $128.4 \pm 14.6^{* *}$ \\
\hline
\end{tabular}

All data \pm standard deviation (SD), each group equal 5 rats, $p<0.05^{*}, p \leq$ $0.01^{* *}, p \leq 0.001^{* * *}$, represented the comparison of EAC+ Seeds Extract and EAC+ Fruit Extract with the EAC group 
antioxidants status as they increase the antioxidant enzymes as well as decrease the TBARS and $\mathrm{H}_{2} \mathrm{O}_{2}$ in the EAC + Seeds Extract and EAC + Fruit Extract groups when compared with EAC group.

The real time PCR results (Figure 1) showed that the expression of $p 53$ and $B c l 2$ genes was decreased in EAC+ Seeds extract group when compared with the EAC one. Also the extract of fruit extract decreased the expression of both genes EAC + Fruit Extract treated group when compared with the EAC group.

\section{Discussion}

The transplantation of EAC neoplastic cells into the mice causes deflection in the balance of antioxidant/oxidative stress system both in EAC and liver tissue. The inhibition of SOD and GSH-Px activities as a result of EAC growth was reported in liver [39]. Corresponding decrease in the levels of SOD and GSH was observed in the liver of EAC-bearing mice [12]. The decrease in the activities of antioxidants may be due to the increase of oxidative stress induced by the inoculation of EAC. There was increase in the levels of thiobarbituric acid reactive substance representing by malondialdehyde (MDA) and hydrogen peroxide in the EAC cells, ascetic fluid and liver homogenates in EAC group when compared with the
EAC treated groups. The extracts of seeds and fruits pulp of Adansonia moderate the levels of MDA and $\mathrm{H}_{2} \mathrm{O}_{2}$ in EAC cells, ascetic fluid and liver homogenates. This amelioration may be due to the antioxidant effect of $\mathrm{Ad}$ ansonia. Vertuani [40] showed that the fruit pulp exhibited strong anti-oxidant activity corresponding to $6-7 \mathrm{mmol} / \mathrm{g}$ of Trolox, in comparison to the fruit pulps of orange $(0.1$ $\mathrm{mmol} / \mathrm{g})$, strawberry $(0.90 \mathrm{mmol} / \mathrm{g})$, apple $(0.16 \mathrm{mmol} / \mathrm{g})$ and kiwi $(0.34 \mathrm{mmol} / \mathrm{g})$. The antioxidant activity of fresh ripe fruit of $A$. digitata was $1000 \mathrm{mg}$ AEAC/100g (ascorbic acid equivalent antioxidant content) [41]. So the significant increase in the antioxidant enzymes activity such as SOD, GSH-Px in EAC and liver due to the higher antioxidant effect of Adansonia. Nhukarume [42] investigated the ability of solvent extracts of various fruits including baobab to inhibit the peroxidetion of lipids. This may explain the significant decrease in the MDA and $\mathrm{H}_{2} \mathrm{O}_{2}$ levels after the treatment with the extract of Adansonia. The hepatoprotective activity of a water extract of the fruit pulp was evaluated in vivo against chemicalinduced toxicity with CCL4 in rats [23]. In the present study, EAC-bearing mice showed to be under higher oxidative stress than control animals indicated by elevated lipid peroxidation and reduced endogenous antioxidants in the liver. Tumors in the human body or in

Table 6. The liver antioxidants activities and oxidative stress in different treated groups.

\begin{tabular}{|c|c|c|c|c|}
\hline Groups Parameters & Control & EAC & EAC+Seeds Extract & EAC+Fruit Extract \\
\hline SOD (U/g tissue) & $32.4 \pm 2.2$ & $14.4 \pm 7.04^{* * *}$ & $22.1 \pm 2.01^{* * * 11}$ & $21.8 \pm 1.9^{* * * \text { III }}$ \\
\hline GSH-Px (U/g tissue) & $107.1 \pm 6.5$ & $86.5 \pm 10.5^{* * *}$ & $103.3 \pm 8.9^{\check{1} .1}$ & $97.6 \pm 11^{*}$ \\
\hline GSH(mg/g tissue) & $96.31 \pm 29.1$ & $54.58 \pm 14.3^{* * *}$ & $84.13 \pm 25.1^{* * * \text { I III }}$ & $84.34 \pm 38.6^{* * * \text { Ǐ III }}$ \\
\hline MDA (n mol/g tissue) & $92.8 \pm 13.7$ & $148.2 \pm 6^{* * *}$ & $126.3 \pm 2.3^{* * *}$ & $132 \pm 5.2^{* * *}$ \\
\hline $\mathrm{H}_{2} \mathrm{O}_{2}(\mathrm{U} / \mathrm{g}$ tissue $)$ & $9.0 \pm 0.91$ & $16.8 \pm 2.2^{* * *}$ & $9.9 \pm 0.89^{\text {İ II }}$ & $11.0 \pm 1.9^{\text {İ II }}$ \\
\hline
\end{tabular}

All data \pm standard deviation $(\mathrm{SD})$, each group equal 5 rats, $p<0.05^{*}, p \leq 0.001^{* * *}$, represented the comparison of EAC, EAC $+\mathrm{Seeds}$ Extract and EAC + Fruit Extract with the control group; $p \leq 0.01$ i⿱丷亡), represented the comparison of EAC+ Seeds Extract and EAC+ Fruit Extract with the EAC group.

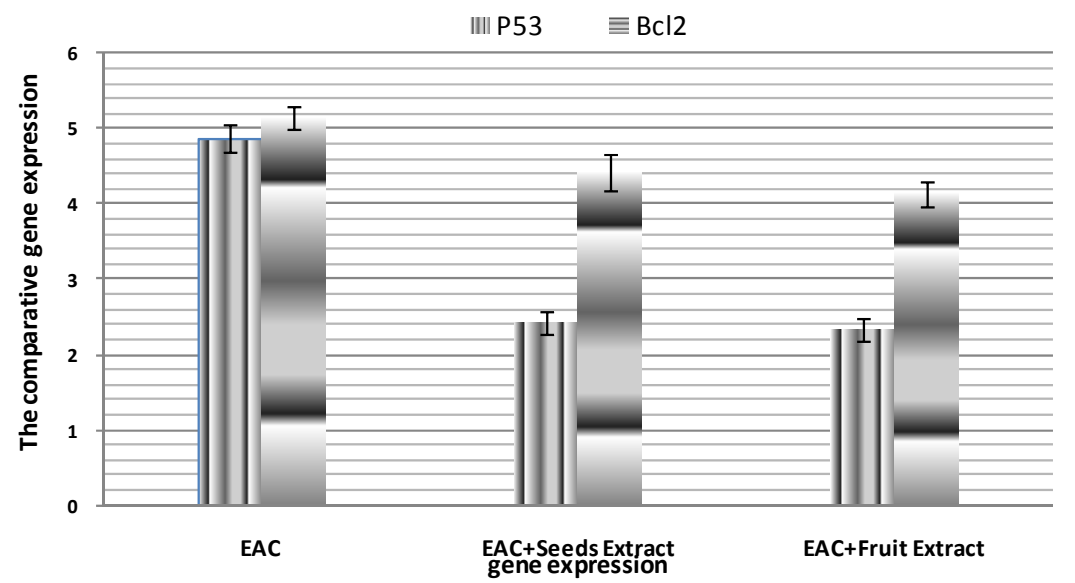

Figure 1. P53 and Bcl2 genes expression in Ehrlich Ascites Carcinoma cells of different groups of rats. 
experimental animals are known to affect many functions of the vital organs, especially the liver, even when the site of the tumor does not interfere directly with organ function [43]. However, the decrease in bilirubin indicates the improvement of liver function, so the treated mice with adansonia improve the liver function. This is may be due totriterpenoids, $\beta$-sitosterol, $\beta$-amyrinpalmitate, and/or $\alpha$-amyrin and ursolic acid present in thefruit pulp [24]. The reduction in oxidative stress leads to subsequent decrease in injury and damage of the hepatocytes membranes. It is suggested that if oxidative stress is involved in the origin of EAC-induced liver oxidative injury, then a successful extract with antioxidant potential should protect against that injury. Seeds and fruit pulp of Adansonia ameliorated oxidative stress in seeds and fruit pulp + EAC-bearing mice and prevented cellular injury as evidenced by a decrease in levels of TBARS in liver. This is associated with increase in GSH level as well as the activities of SOD, and GSH-Px compared with EACimplanted mice. The control of endogenous redox state might contribute to the demonstrated increase in the life span of EAC-tumor bearing mice treated with Adansonia. Thus, the tumor markers such as $\alpha$-l-fucosidase and arginase indicate that Adansonia exhibited significant antitumor and might show potential antioxidant activity in EAC-bearing mice. This might be via changes in the expression of endogenous antioxidants. The administration of seeds and fruit pulp of Adansonia significantly increased the levels of GSH, SOD and GSH-Px as well as decreased lipid peroxidation in EAC cells, ascetic fluid and liver homogenate compared with that obtained from control EAC group. This indicates that Adansonia extracts altered the redox state in the sera, EAC cells, ascetic fluid and liver tissue.

Apoptosis is a programmed cell death where the cell expends energy towards its own end. It is well known that functional $p 53$ provides a protective mechanism against tumor growth. It acts as a tumor suppressor through its capacity to induce cell cycle arrest and apoptosis in response to a variety of chemotherapeutic drugs [44]. Cell growth and its proliferation are two tightly linked processes. Both are characterized by increased protein synthesis which is achieved by changes in the activity of ribosomal biogenesis and $p 53$ expression [16]. It is reported that deregulated signaling in cancer cells drives excessive ribosome biogenesis within the nucleolus, which elicits uncontrolled cell growth and proliferation. It is controlled by a complex interconnection of proteins such as $p 53$ and is often triggered by oxidative stress and the release of cytochrome $c$ from the mitochondria [19]. Bcl-2 indicates a family of genes and proteins found in rats that regulates the outer membrane permeability of mitochondria, and most importantly the fate of the cell through programmed cell death, apoptosis.
The increased level of ROS is involved in generating the signal that causes change the permeability of the mitochondrial membrane, and, thus, the release of cytochrome $c$ into the cytosol. Once this occurs, the initiation of the cascade of caspases occurs [45]. Activation of caspases will eventually lead to the death of the cell and other surrounding cells. $\mathrm{H}_{2} \mathrm{O}_{2}$-induced apoptosis is accompanied by changes in apoptosis-related factors such as the $B c l-2$ family of regulatory proteins [19]. However, ROS such as $\mathrm{H}_{2} \mathrm{O}_{2}$ act not only as cellular messengers capable of causing oxidative damage to macromolecules, but also as signaling molecules that activate protein kinase cascades [46]. The high expression of $p 53$ and $B c l-2$ genes due to their molecular changes accompanied with tumor development in mice. The impairment of nucleolar function might stabilize $p 53$ by preventing its degradation and, therefore, for the arrest of cell-cycle progression [10]. Therefore, the present finding indicatesthat seeds and fruit pulp of Adansonia might be able to attenuate apoptotic mechanisms through the changes of $\mathrm{p} 53$ and $\mathrm{Bcl}-2$ gene expression leading to the control of growth and proliferation of EAC cells.

\section{Conclusion}

The study demonstrated that extracts of seeds and fruit pulp of Adansoniacould have anti-tumor action through modulation of redox state in sera, EAC cells, ascetic fluid and liver tissue. These extracts were able to restore and modulate the tumor markers levels such as $\alpha$-l-fucosidase and arginase activity in the sera of EAC bearing mice. Also Adansonia attenuates the $p 53$ and $B c l-2$ gene expression as pro-apoptic and anti-apoptic genes leading to management of tumor growth. The study initiates human to use Adansonia as a good edible stuff that has strong antioxidant action and anti-tumor agent.

\section{Acknowledgements}

The author appreciates the helpful effort of his colleagues Dr. Ali H. Amin and Dr. Mohammed E. Elbeeh, zoology department, faculty of science, Mansoura University, Egypt, during the practical part of this work.

\section{REFERENCES}

[1] Ö Kaleoglu and N. Isli, "Ehrlich-Lettre Asit Tümörü," Tıp Fakültesi Mecmuası, Vol. 40, No. 1, 1977, pp. 978984.

[2] H. G. Okay, "Deneysel EAT Olu_turulan Fare Karaciger Plazmasında Nitrik Oksit Metabolizmasının Incelenmesi. Yüksek Lisans Tezi," Istanbul Üniversitesi Saglık Bilimleri Enstitüsü, Biyokimya ABD, Istanbul, 1998.

[3] H. Gümüshan and I.P., I.V. ve S.C., "Yollarla Uygulanan Adriamycin'in Ehrlich Asit Tümörü (EAT) Tasıyan Fare- 
lere Etkileri Üzerine Bir Çalısma," Harran Üniversitesi Fen Bilimleri Enstitüsü, Yüksek Lisans Tezi, Sanlıurfa, 2002.

[4] Z. Song, J. Varani and I. J. Goldstein, "Differences in Cell Surface Carbohydrates, and in Laminin and Fibronectin Synthesis between Adherent and Non-Adherent Ehrlich Ascites Tumor Cells," International Journal of Cancer, Vol. 55, No. 6, 1993, pp. 1029-1035. doi:10.1002/ijc.2910550625

[5] Ö. Bulan, "Ehrlich Ascites Tümör Hücrelerinde Yaslanmaile Hücre Kinetigi Arasındaki Iliskiler," YüksekLisans Tezi, IstanbulÜniversitesi Fen Bilimleri Enstitüsü, Istanbul, 1990.

[6] E. Aktas, Ehrlich Asit Sıvısının L-Hücrelerinin Çogalma Hızına Etkisi," Yüksek Lisans Tezi, Istanbul Üniversitesi Fen Bilimleri Enstitüsü, Istanbul, 1996.

[7] M. Ozaslan, I. D. Karagoz, I. H. Kilic and M. E. Guldur, "Ehrlich Ascites Carcinoma," African Journal of Biotechnology, Vol. 10, No. 13, 2011, pp. 2375-2378.

[8] S. Altun, "Normal, Tümöralve Rejeneratif Büyümeler Arasindaki Kinetik Iliskiler," Turkish Journal of Biology, Vol. 20, No. 3, 1996, pp. 153-173.

[9] T. Andoh, P. B. Chock and C. C. Chiueh, "The Roles of Thioredoxin in Protection against Oxidative Stress-Induced Apoptosis in SH-SY5Y Cells," The Journal of Biological Chemistry, Vol. 277, 2002, pp. 9655-9660. doi:10.1074/jbc.M110701200

[10] M. R. Bleavins, D. A. Brott, J. D. Alvey and F. A. de la Iglesia, "Flow Cytometric Characterization of Lymphocyte Subpopulations in the Cynomolgus Monkey (Macaca fascicularis)," Veterinary Immunology and Immunopathology, Vol. 37, No. 1, 1993, pp. 1-13. doi:10.1016/0165-2427(93)90011-R

[11] C. Lobo, M. A. Ruiz-Bellido, J. C. Aledo, J. Marquez, I. N. De Castro and F. J. Alonso, "Inhibition of Glutaminase Expression by Antisense mRNA Decreases Growth and Tumourigenicity of Tumour Cells," Biochemical Journal, Vol. 348, 2000, pp. 257-261. doi:10.1042/0264-6021:3480257

[12] M. A. El-Missiry, A. I. Othman, M. A. Amer and E. Mohamed, "Ottelione a Inhibited Proliferation of Ehrlich Ascites Carcinoma Cells in Mice," Chemico-Biological Interactions, Vol. 200, No. 2-3, 2012, pp. 119-127. doi:10.1016/j.cbi.2012.10.013

[13] D. Li, E. Ueta, T. Kimura, T. Yamamoto and T. Osaki, "Reactive Oxygen Species (ROS) Control the Expression of Bcl-2 Family Proteins by Regulating Their Phosphorylation and Ubiquitination," Cancer Science, Vol. 95, No. 8, 2004, pp. 644-650. doi:10.1111/j.1349-7006.2004.tb03323.x

[14] H. Xu, R. J. Steven and X. M. Li, "Dose-Related Effects of Chronic Antidepressants on Neuroprotective Proteins BDNF, Bcl-2 and Cu/Zn-SOD in Rat Hippocampus," Neuropsychopharmacology, Vol. 28, 2003, pp. 53-62. doi:10.1038/sj.npp.1300009

[15] T. Das, G. Sa, P. Sinha and P. K. Ray, "Induction of Cell Proliferation and Apoptosis: Dependence on the Dose of the Inducer," Biochemical and Biophysical Research Communications, Vol. 260, No. 1, 1999, pp. 105-110. doi:10.1006/bbrc. 1999.0712

[16] G. Donati, L. Montanaro and M. Derenzini, "Ribosome Biogenesis and Control of Cell Proliferation: p53 Is Not Alone," Cancer Research, Vol. 72, 2012, pp. 1602-1607. doi:10.1158/0008-5472.CAN-11-3992

[17] T. Miyashita and J. C. Reed, "Tumor Suppressor p53 Is a Direct Transcriptional Activator of the Human Bax Gene," Cell, Vol. 80, No. 2, 1995, pp. 293-299. doi:10.1016/0092-8674(95)90412-3

[18] T. Miyashita, S. Krajewski, M. Krajewska, H. G. Wang, H. K. Lin, D. A. Liebermann, B. Hoffman and J. C. Reed, "Tumor Suppressor p53 Is a Regulator of Bcl-2 and Bax Gene Expression in Vitro and in Vivo," Oncogene, Vol. 9, No. 6, 1994, pp. 799-1805.

[19] D. H. Cho, T. N. Tomohiro, J. Fang, P. Cieplak, A. Godzik, Z. Gu and S. A. Lipton, "S-Nitrosylation of Drp1 Mediates $\beta$-Amyloid-Related Mitochondrial Fission and Neuronal Injury," Science, Vol. 324, No. 5923, 2009, pp. 102105. doi:10.1126/science. 1171091

[20] X. R. Cheng, L. Zhang, J. J. Hu, L. Sun and G. H. Du, "Neuroprotective Effects of Tetramethylpyrazine on Hydrogen Peroxide-Induced Apoptosis in PC12 Cells," Cell Biology International, Vol. 31, 2007, pp. 438-443. doi:10.1016/j.cellbi.2006.10.001

[21] M. Ozaslan, I. D. Karagöz, M. E. Kalender, I. H. Kilic, I. Sari and A. Karagöz, "In Vivo Antitumoral Effect of Plantago major L. Extract on Balb/C Mouse with Ehrlich Ascites Tumor," The American Journal of Chinese Medicine, Vol. 35, No. 5, 2007, pp. 841-851. doi:10.1142/S0192415X07005314

[22] G. M. Cragg and D. J. Newman, "Discovery and Development of Antineoplastic Agents from Natural Sources," Cancer Investigation, Vol. 17, No. 2, 1999, pp. 153-163.

[23] G. P. P. Kamatou, I. Vermaak and A. M. Viljoen, "An Updated Review of Adansonia digitata: A Commercially Important African Tree," South African Journal of Botany, Vol. 77, No. 4, 2011, pp. 908-919. doi:10.1016/j.sajb.2011.08.010

[24] A. A. Al-Qarawi, M. A. Al-Damegh and S. A. El-Mougy, "Hepatoprotective Influence of Adansonia digitata Pulp," Journal of Herbs Spices and Medicinal Plants, Vol. 10, No. 3, 2003, pp. 1-6. doi:10.1300/J044v10n03 01

[25] C. Buchmann, S. Prehsler, A. Hartl and C. R. Vogl, "The Importance of Baobab (Adansonia digitata L.) in Rural West African Subsistence-Suggestion of a Cautionary Approach to International Market Export of Baobab Fruits," Ecology of Food and Nutrition, Vol. 49, No. 3, 2010, pp. 145-172. doi:10.1080/03670241003766014

[26] R. Addy, "Baobab Fruit Approved as Food Ingredient in US," 2009.

http://www.nutraingredientsusa.com/content/view/print/2 59574,2009.

[27] A. C. Sanchez, P. E. Osborne and N. Haq, "Identifying the Global Potential for Baobab Tree Cultivation Using Ecological Niche Modeling," Agroforestry Systems, Vol. 80, No. 2, 2010, pp. 191-201. doi:10.1007/s10457-010-9282-2

[28] J. Gebauer, K. El-Siddig and G. Ebert, "Baobab (Adan- 
sonia digitata L.): A Review on a Multipurpose Tree with Promising Future in Sudan," Gartenbauwissenschaft, Vol. 67, No. 4, 2002, pp. 155-160.

[29] S. Vertuani, E. Braccioli, V. Buzzoni and V. S. Manfredini, "Antioxidant Capacity of Adansonia Digitata Fruit Pulp and Leaves," Acta Phytotherapeutica, Vol. 5, No. 2, 2002, pp. 2-7.

[30] A. A. Shahat, "Procyanidins from Adansonia digitata," Pharmaceutical Biology, Vol. 44, No. 6, 2006, pp. 445450. doi:10.1080/13880200600798510

[31] R. A. Mothana, U. Lindequist, R. Gruenert and P. J. Bednarski, "Studies of the in Vitro Anticancer, Antimicrobial and Antioxidant Potentials of Selected Yemeni Medicinal Plants from the Island Soqotra," BMC Complementary \& Alternative Medicine, Vol. 9, 2009, pp. 7-18. doi:10.1186/1472-6882-9-7

[32] M. Nishikimi, N. A. Rao, et al., "The Occurrence of Superoxide Anion in the Reaction of Reduced Phenazine Methosulfate and Molecular Oxygen," Biochemical and Biophysical Research Communications, Vol. 46, No. 2, 1972, pp. 849-854. doi:10.1016/S0006-291X(72)80218-3

[33] G. L. Ellman, "Tissue Sulfhydryl Groups," Archives of Biochemistry and Biophysics, Vol. 82, No. 1, 1959, pp. 70-77. doi:10.1016/0003-9861(59)90090-6

[34] E. Beutler, O. Duron, B. M. Kelly, "Improved Method for the Determination of Blood Glutathione," The Journal of Laboratory and Clinical Medicine, Vol. 61, No. 1, 1963, pp. 882-888.

[35] H. Ohkawa, N. Ohishi, et al., "Assay for Lipid Peroxides in Animal Tissues by Thiobarbituric Acid Reaction," Analytical Biochemistry, Vol. 95, No. 2, 1979, pp. 351358. doi:10.1016/0003-2697(79)90738-3

[36] H. Aebi, "Catalase in Vitro," Methods in Enzymology, Vol. 105, 1984, pp. 121-126. doi:10.1016/S0076-6879(84)05016-3

[37] M. Walter and H. Gerade, "An Ultramicromethod for the Determination of Conjugated and Total Bilirubin in Serum or Plasma," Microchemical Journal, Vol. 15, No. 2, 1970, pp. 231-243. doi:10.1016/0026-265X(70)90045-7

[38] A. Lamien-Meda, C. E. Lamien, M. M. Y. Compaoré, R.
N. T. Meda, M. Kiendrebeogo, B. Zeba, J. F. Millogo and O. G. Nacoulma, "Polyphenol Content and Antioxidant Activity of Fourteen Wild Edible Fruits from Burkina Faso," Molecules, Vol. 13, No. 3, 2008, pp. 581-594. doi:10.3390/molecules13030581

[39] M. Gupta, U. K. Mazumder, R. S. Kumar, T. Sivakumar and M. L. Vamsi, "Antitumor Activity and Antioxidant Status of Caesalpinia Bonducella against Ehrlich Ascites Carcinoma in Swiss Albino Mice," Journal of Pharmacological Science, Vol. 94, 2004, pp. 177-184.

[40] A. Lamien-Meda, C. E. Lamien, M. M. Compaoré, R. N. Meda, M. Kiendrebeogo, B. Zeba, J. F. Millogo and O. G. Nacoulma, "Polyphenol Content and Antioxidant Activity of Fourteen Wild Edible Fruits from Burkina Faso," Molecules, Vol. 13, No. 3, 2008, pp. 581-594. doi:10.3390/molecules 13030581

[41] L. Nhukarume, Z. Chikwambi, M. Muchuweti and B. Chipurura, "Phenolic Content and Antioxidant Capacities of Parinari curatelifolia, Strychnos spinosa and Adansonia digitata," Journal of Food Biochemistry, Vol. 34, Suppl. 1, 2008, pp. 207-221. doi:10.1111/j.1745-4514.2009.00325.x

[42] N. Senthilkumar, S. Badami, S. H. Dongre and S. Bhojraj, "Antioxidant and Hepatoprotective Activity of the Methanol Extract of Careya arborea Bark in Ehrlich Ascites Carcinoma-Bearing Mice," Journal of Natural Medicines, Vol. 62, No. 3, 2008, pp. 336-339. doi:10.1007/s11418-008-0237-0

[43] C. P. Rubbi and J. Milner, "P53: Guardian of a Genome's Guardian? Cell Cycle, Vol. 2, No. 1, 2003, pp. 20-21. doi:10.4161/cc.2.1.297

[44] M. P. Mattson, "Apoptosis in Neurodegenerative Disorders," Nature Reviews. Molecular Cell Biology, Vol. 1, No. 2, 2000, pp. 120-129. doi:10.1038/35040009

[45] R. B. Petersen, A. Nunomura, H. G. Lee, G. Casadesus, G. Perry, M. A. Smith and X. Zhu, "Signal Transduction Cascades Associated with Oxidative Stress in Alzheimer's Disease," Journal of Alzheimer's Disease, Vol. 11, No. 2, 2007, pp. 143-152. 